\title{
Spermatocytic seminoma
}

\author{
症例報告ならびに文献的考察 \\ 安城更生病院泌尿器科 (部長 : 和志田裕人) \\ 津ヶ谷正行* 和志田裕人 平尾 憲昭* \\ 岩瀬豊* 阪上洋 \\ SPERMATOCYTIC SEMINOMA \\ Case Report and Review of the Literature \\ Masayuki Tsugaya, Hiroto Washida, Noriaki Hirao, \\ Yutaka Iwase and Hiroshi Sakagami \\ Department of Urology, Anjo Kosei Hospital \\ (Chief: H. Washida)
}

Bilateral spermatocytic seminoma in 50-year-old man was described. Bilateral orchiectomy and preventive irradiation therapy for retroperitoneal lymphonodes were performed. The patient is doing well after 3.7 years' postoperative follow-up without clinical evidence of metastatic disease.

The literature on the spermatocytic seminoma was reviewed. The review of 2981 testicular seminomas disclosed 115 of the spermatocytic type. The patients with spermatocytic seminoma were distinctly older than those with classical seminoma: the peak incidence on the 40 to 49 and 65 to 74 age groups, mean 55.7 year-old. Bilaterality in 8 of 74 cases with spermatocytic seminoma in the literature was more frequent than that with classical seminoma. This neoplasm had good prognosis and was rarely associated with metastasis.

\footnotetext{
要旨：50歳の両側性 spermatocytic seminoma の 1 症例を報告した. 両側除辠術ならびに後腹膜リンパ 節に対し予防的な放射線照射を施行し, 術後 3.7 年を経過した現在, 再発・転移は認められない。

文献上本腫瘍を集計し統計的考察を加えた。 2 ,981例の testicular seminoma の中で本腫瘍は115例で あった。本腫瘍は classical seminoma に比べて高齢者に多く, 年齢分布では40歳から49歳と65歳から74 歳に peak を示し, 平均55.7歳であった。両側症例は74例中 8 例で, classical seminoma に比べて高率 であった。本腫瘍は転移を来たすことは稀で, 予後は良好であった。
}

\section{緒 言}

Spermatocytic seminoma $は$ classical seminoma と異なる亜型として1946年 Masson ${ }^{11}$ とって報告さ れたが，当時はあまり注目されなかった。近年本腫瘍 が次々と報告されるようになり，本邦では1968年に友 吉ら ${ }^{2)}$ が第 1 例を報告した。著者らの経験した本腫瘍 の両側性の 1 症例の報告之, 本邦ならびに欧米の症例 を集計し，文献的考察を加えた。

$$
\text { 症例 }
$$

患者：50歳, 男性, 自営業。

初診：1983年 2 月 9 日。

家庭歴：既往歴。特記すべきことなし。

* 現 名古屋市立大学医学部泌尿器科学教室
現病歴： 5 年程前から両側陰囊内容が徐々に腫大し てきたが，疼痛はないため放置していた。両側陰囊内 容がさらに腫大し，作業に支障をきたすようになった ため当科を受診した。

右陰囊内容は超手挙大, 左側が超黛卵大に腫大, 両 側とも表面平滑, 弾性硬で圧痛や透光性なし。他に理 学的異常所見を認めない。

尿, 血液学的検査で $\mathrm{LDH}$ は $369 \mathrm{mU} / \mathrm{ml}$ で正常上限 を示したが, 腫瘍マーカー, その他はすべて正常。胸 部 X 線像。IVP は正常。陰囊部超音波検査で充実性の 巨大な両側睪丸を認め, 内部ェコー像は一部不均一で 分葉化していた。以上から両側睪丸腫瘍と診断し, 同 年 2 月 10 日両側除辠術を施行した。右睪丸は $390 \mathrm{~g}$, $10 \times 7 \times 3.5 \mathrm{~cm}$, 左粹丸は $210 \mathrm{~g}, 8 \times 6 \times 3.3 \mathrm{~cm}$ で副辠丸 
は両側とも圧排，希薄したためか判別困難であった。 割面は左右とも黄灰色，充実性で一部に出血や壊死を 認め，大小様々な結節状を呈し，正常睪丸組織は認め られなかった (Fig. 1).

病理組織学的所見。髄様に増生した腫瘍細胞は円形 核で好ェオジン性の胞体を有する細胞と巨大な単核あ るいは 2 核の核網が粗な核と好エオジン性胞体を持つ 精母細胞に類似した細胞，小形でリンパ球様のクロマ チン濃染核で赤い胞体を持つ細胞，以上 3 種類の細胞

Fig. 1 Gross appearance of the neoplasm. The lesion is lobulated, grayish yellow with small gelatinous and hemorrhagic degeneration.

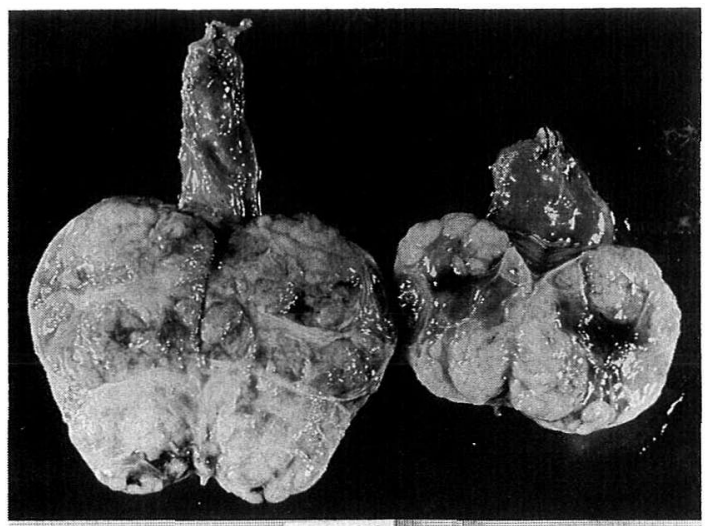

83030
からなる.PAS 染色では腫瘍細胞の細胞質は陰性を示 した。睪丸は両側とも同様な所見で teratoma の部位 は認められなかった。 以上の所見から spermatocytic seminoma と診断された（Fig. 2)。また副睪丸への浸 潤は認められなかった。

術後, リンパ管造影では異常所見は認められなかっ たが，予防的に傍大動脈部々骨盤部のリンパ節に対し 3,500 rad の放射線照射を施行した。術前に正常上限を 示した $\mathrm{LDH}$ は術後 2 日目に $265 \mathrm{mU} / \mathrm{ml}$ と下降し，以 後上昇は認められなかった。術後 3 年 8 力月を経過し た現在，再発の徴候は認められていない。

\section{考察}

本邦における spermatocytic seminoma は1985年本 多ら 3)が 9 例を集計し, 著者らが調べた限りでは自験 例は本邦11例目であった2) 6)。一方，欧米では1969年

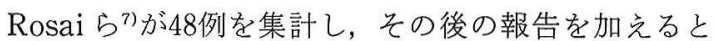
150例が報告されている117) 27)。欧米ならびに本邦例 161例中で本腫瘍の頻度, 年齢分布, 罹患側, 発症から 手術までの期間，症状，転移ないし浸潤ならびに予後 について記載されていた症例に関して統計的考察を 行った。

\section{1) 頻度}

Spermatocytic seminoma が seminoma の中で占 める割合は1.7〜 $12.1 \%$ と報告されてい る7) 13)16)18)19)22) 26). これらの報告をまとめたところ本

Fig. 2 Microscopic section shows round nuclei which are variable in size and staining characteristics. (H. \& E., $\times 300$ and $\times 600)$

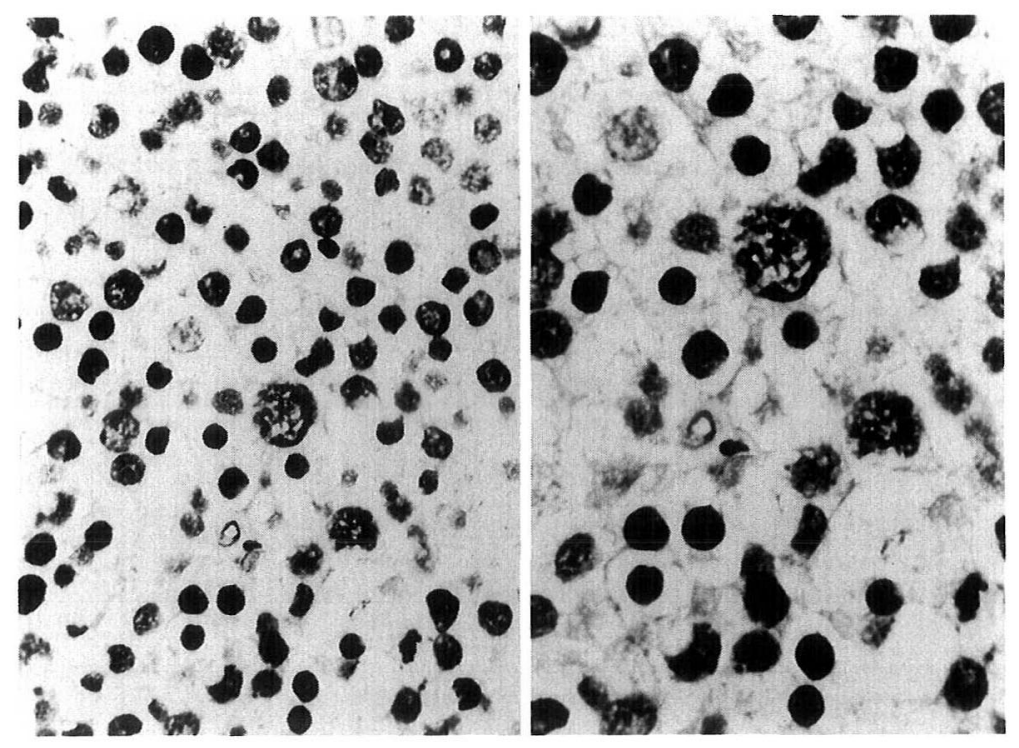


Fig. 3 Distribution of age and site.

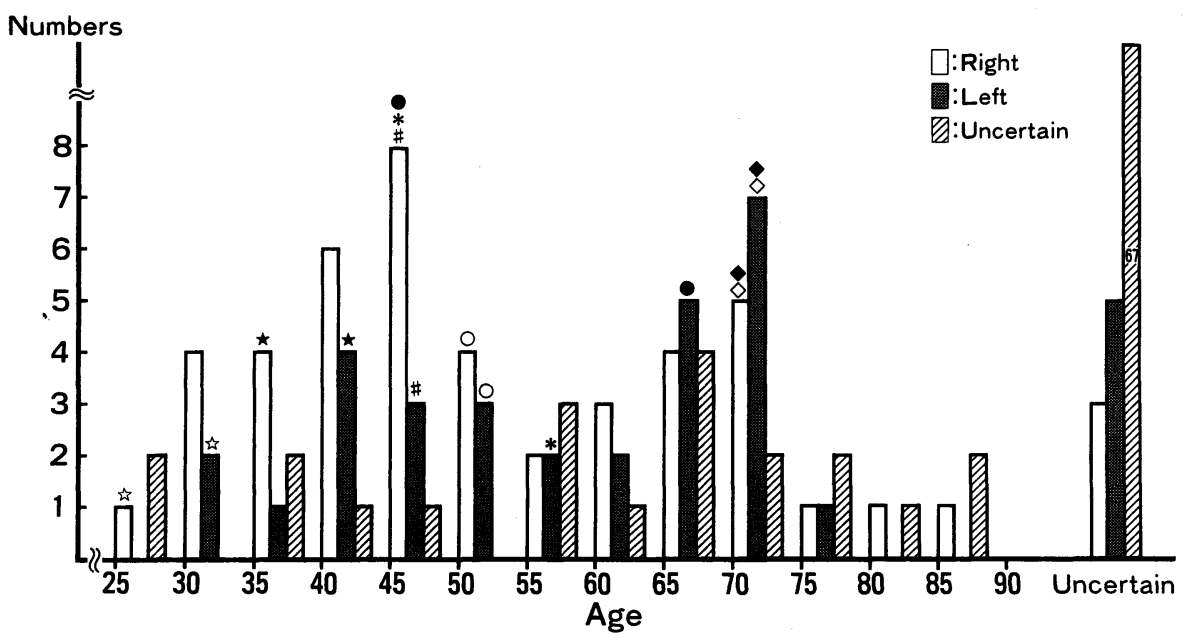

Bilateral 8 cases are showed by the marks : $\star * \# 0 \diamond$

Fig. 4 Preoperative duration since onset.

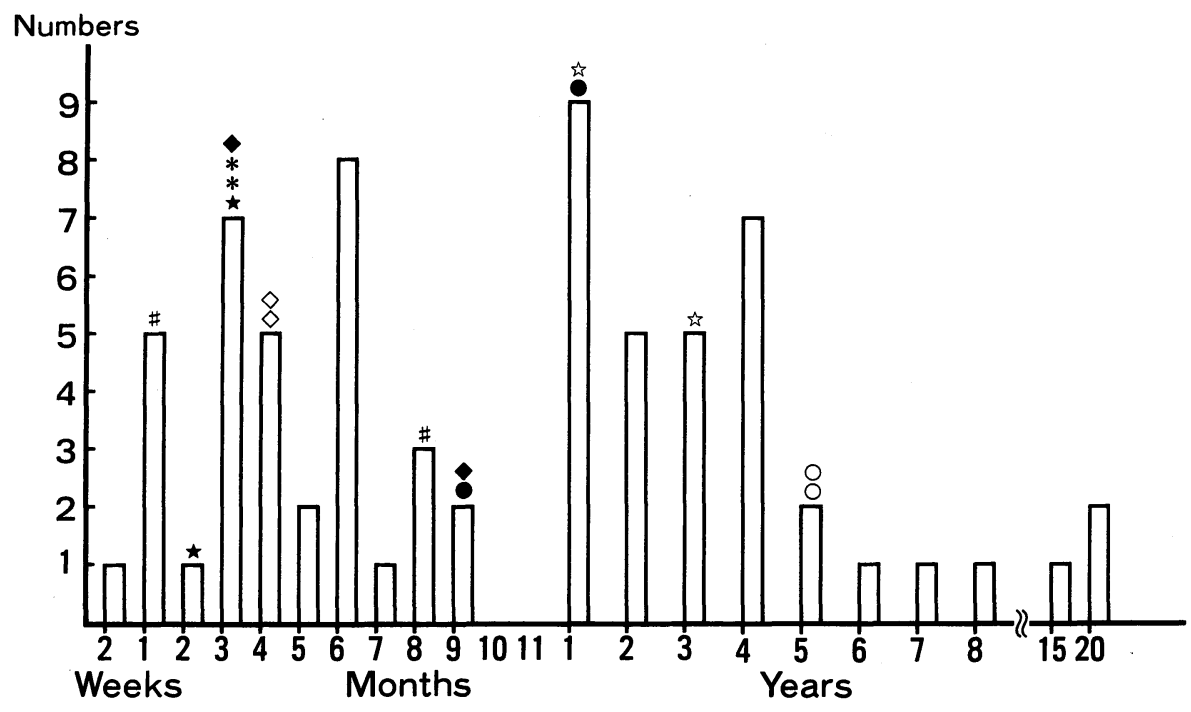

Bilateral 8 cases are showed by the marks:

腫瘍の seminoma 中の頻度は2,981例中115例， $3.9 \%$ と低率であった。

2) 年齢分布

集計した161例中年齢記載のある86例の年齢分布は 25歳から89歳で, 平均55.7歳, 40歳から49歳と65歳か ら74歳に peakを示し, 本腫瘍は classical seminoma に比べて ${ }^{16)}$ ，高齢者に多いことが示唆された(Fig. 3).

3）罹患側

本邦 11 例では右側 7 例, 左側 1 例, 両側 3 例で右側
が有意に多い.今回の集計症例中罹患側が記載されて いる74例では右側39例，左側27例，両側 8 例であった (Fig. 3). 両側症例中同じ年代で本腫瘍の発生を認め た症例は 4 例であるが，同時発生と考光られる症例は 2 例であった（Fig. 3，4）。両側粹丸腫瘍の頻度は $3.14 \%$ ， seminoma に拈ける両側症例の頻度は $1.78 \%$ と報告 ${ }^{16)}$ れているのに対し, 本腫瘍では両側症例が 11\%と高率であった.

4）発症から手術までの期間および症状 
発症から手術までの期間について記載されていた 61 例69腫瘍を Fig. 4 に示す. 発症から 1 年以上経過して いた症例は 61 例中 31 例で半数を占め, 5 年以上経過し

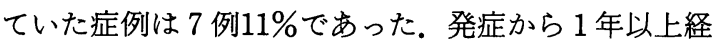
過していた症例の腫瘍の大きさは通常大きく，20年経 過していた 1 症例では $30 \mathrm{~cm}, 1,500 \mathrm{~g}^{16)}$ と巨大であっ た.

症状は陰囊内容の腫大を主訴とした症例が大多数 で，主訴が記載された報告例中疼痛を伴った症例は 3 例であった ${ }^{24) 18)}$.

5）転移ないし浸潤ならびに予後

Jackson ら ${ }^{10}$ は本腫瘍の 5 例中 4 例が転移によって 死亡したと報告している。しかし Rosai らが Jackson ら ${ }^{10)}$ の症例の標本を再検討したところ上記転移の 4 症 例はいずれも anaplastic tumorで本腫瘍とは認め難 いと報告している77. 文献上転移症例は垣内らの奇形 腫を合併した肝・肺転移の 1 症例5), Schoborg らのリ ソパ節転移の 1 症例 ${ }^{20)}$ ，Serov らの小骨盤腔内転移の 1 症例 ${ }^{14)}$ ならびに Masson ${ }^{11}$ の転移 2 症例, 計 5 例が報 告されている。これらの症例の中には Jackson ら ${ }^{10)} の$ 症例のような anaplastic tumor を含んでいる可能性 が考学られる。

浸潤については Sully9), Jackson ら ${ }^{10)}$, Rosai ら7, 本多ら ${ }^{3)}$ の症例で細精管への腫瘍細胞の浸潤や副睪丸 などの周囲組織への浸潤が報告されている，浸潤につ いての詳細な検討を行った報告が少ないため浸潤の頻 度は不明である。

本腫瘍は前記のように転移が極めて稀であり, 発症 から手術まで 1 年以上経過した症例が約半数を占め, これらの症例中に転移がないこと, 放射線感受性が高 いことから予後は良好と考兄られる。しかし特異な症 例もあるため十分な経過観察が必要である。

\section{結語}

50歳男子にみられた両側悬丸腫瘍に対し両側除辠術 を行い, 病理組織学的に spermatocytic seminoma 診断された 1 症例を報告した。術後予防的に $3,500 \mathrm{rad}$ の放射線照射を施行, 術後 3 年以上経過した現在, 再 発・転移をみない，本症例は本邦11例目で, 欧米の文 献から150例を集計し，これらの症例とともに統計的考 察を加えた。

本腫瘍が seminoma の中で占める割合は $3.9 \%$ で あった。年齢分布は40歳から49歳と65歳から74歳に peak を示し, 平均 55.7 歳であった。両側症例が $11 \%$ と 高率に認められた。転移は稀で予後は通常良好であっ
た。

本論文の要旨は 1985 年 5 月 25 日, 第 148 回東海泌尿器科学 会に於いて発表した。

\section{文献}

1) Masson, P.: Etude sur seminome. Rev. Canad. Biol., 5, 361-387, 1946.

2) 友吉唯夫, 川村寿一: 両側性 Spermatocytic seminoma の 1 例. 泌尿紀要, 14, 753-757, 1968.

3）本多正人, 多田安温, 並木幹夫, 奥山明彦, 大西俊 造：Spermatocytic seminoma の 1 例. 西日泌尿, 47, 1397-1400, 1985.

4）西 正夫, 野溝昌成: Spermatocytic seminoma の 1 例。 日泌尿会誌，61，1035，1969.

5）垣内史堂, 原田 尚, 大谷五良, 松本 棓, 浦野順 文, 加藤綾子：巨大な肝転移をきたし，奇型腫を合 併した spermatocytic seminoma の 1 例. 内科, 33, 169-172, 1974.

6）佐藤和宏, 折笠精一, 今井克忠: 精巣腫場の組織発 生に関する電顕学的研究. 第 1 報. Spermatocytic seminoma の電顕的観察. 日泌尿会誌，75，1939 -1948, 1984.

7) Rosai, J., Silber, I. and Khodadoust, K.: Spermatocytic seminoma I. Clinicopathologic study of six cases and review of the literature. Cancer, 24, 92-102, 1969.

8) Negri, L. and Smorlesi, L.: La citologia dei tumori della gonade maschile come criterio discriminativo di istogenesi e di diagnosis oncologica. Arch. De Vecchi Anat. Pat., 18, 747 $-853,1952$.

9) Scully, R.E.: Spermatocytic seminoma of the testis. A report of 3 cases and review of the literature. Cancer, 14, 788-794, 1961.

10) Jackson, J.R. and Magner, D.: Spermatocytic seminoma. A variant of seminoma with specific microscopical and clinical characteristics. Cancer, 18, 751-755, 1965.

11) Giraldo, G. and Ribacchi, R.: II Seminoma spermatocitico. Lavori Ist. Ant. Univ. Perugia, 26, 157-164, 1966.

12) Mikulowski, P. and Szczudrawa, J.: Remarks on the pathology and classification of seminoma spermatocyticum. Acta Medica Polona, 8, 129-136, 1967.

13) Fox, J.E. and Abell, M.R.: Spermatocytic seminoma. J. Urol., 100, 757-761, 1968.

14) Servo, R.A. and Vasiliev, I.V.: Spermatocytic seminoma with fatal outcome. Arch. Patal., 35, 74-75, 1973.

15) Dymock, R.B.: Spermatocytic seminoma. Med. J. Aust., 2, 18-20, 1976. 
16) Thackray, A.C. and Crane, W.A.J.: Seminoma in Pathology of the testis. Pugh R.C.B. ed 164-178, Oxford. Blackwell Scientific Publications, 1976.

17) Sadi, A., Michalany, J., Nogueira, H.E. and Alves, A.C.: Seminoma espermatocitário. Rev. Ass. Med. Brasil, 23, 117-118, 1977.

18) Talerman, A.: Spermatocytic seminoma clinicopathological study of 22 cases. Cancer, 45, 2169-2176, 1980.

19) Walter, P.: Seminome spermatocytaire Etude de 8 observations et revue de la littérature. Virchows Arch. A Path. and Histol., 386, 175-187, 1980.

20) Schoborg, T.W., Whittaker, J. and Lewis, C.W.: Metastatic spermatocytic seminoma. J. Urol., 124, 739-741, 1980.

21) Bergner, D.M., Duck, B. and Rao, M.: Bilateral sequential spermatocytic seminoma. J. Urol., 124, 565, 1980.

22) Frasik, W.: Nasieniak spermatocytowy. Analiza kliniczno-pathologiczna 10 przypadkow. Pat. Pol., 33, 149-158, 1982.
23) Stiller, D., Katenkamp, D., Pre $\beta$ ler, H. and Kosmehl, H.: Keimzelltumoren des Hodens: Histologische Klssifikation von 552 Fällen entsprechend der WHO-Nomenklatur. Zbl. allg. Pathol. u. pathol. Anat., 128, 85-100, 1983.

24) Jacobsen, G.K., Barlebo, H., Olsen, J., Schultz, H.P., Starklint, H., Sogaard, H., Vaeth, M. and the DATECA Study Group: Testicular germ cell tumors in Denmark 1976-1980 Pathology of 1058 consecutive cases. Acta Radiol. Oncol., 23, 239-247, 1984.

25) Jose, B., Perkins, P.L., Kays, H., Chu, A.M. and Sharma, S.C.: Radiation therapy of seminoma of the testis. J. Surg. Oncol., 28, 1-3, 1985.

26) Hochstetter, A.R., Sigg, C., Saremaslani, P. and Hedinger, $C$.: The significance of giant cells in human testicular seminomas. Virchows Arch., 407, 309-322, 1985.

27) Lee, M.C., Talerman, A., Oosterhuis, J.W. and Damjanov, I. : Lectin histochemistry of classic and spermatocytic seminoma. Arch. Pathol. Lab. Med., 109, 938-942, 1985.

（1987年 6 月 1 日受理） 